\title{
Family Dynamics, Fertility Cults, and Feminist Critiques: The Reception of Hosea 1-3 through the Centuries
}

\author{
Bradford A. Anderson
}

Citation: Anderson, Bradford A 2021. Family Dynamics, Fertility Cults, and Feminist Critiques: The Reception of Hosea 1-3 through the Centuries. Religions 12: 674. https:// doi.org/10.3390/rel12090674

Academic Editor: Franz Winter

Received: 19 July 2021

Accepted: 18 August 2021

Published: 24 August 2021

Publisher's Note: MDPI stays neutral with regard to jurisdictional claims in published maps and institutional affiliations.

Copyright: (C) 2021 by the author. Licensee MDPI, Basel, Switzerland. This article is an open access article distributed under the terms and conditions of the Creative Commons Attribution (CC BY) license (https:// creativecommons.org/licenses/by/ $4.0 /)$.
School of Theology, Philosophy, and Music, Dublin City University, D09 N920 Dublin, Ireland; brad.anderson@dcu.ie

\begin{abstract}
This article examines a number of contested and contentious issues in the reception of Hosea $1-3$, exploring how readers through the centuries have engaged with the interpretive challenges found in the initial chapters of this prophetic text. These include (1) debates concerning whether the marriage of Hosea and Gomer should be understood literally or figuratively; (2) questions concerning the identity of the woman in chp. 3 in relation to the events of chp. 1 ; (3) proposals on how to understand the metaphorical elements related to Hosea's marriage and Israel's infidelity; (4) ethical, theological, and rhetorical concerns raised by these chapters, including feminist critiques; (5) the place of Gomer's children in the opening chapter of the book; (6) the themes and rhetoric of chp. 2, including the punishment and wooing of the wife and Israel; and (7) the role of Hos 1-3 in Jewish and Christian liturgical traditions. This study offers soundings from across historical, religious, and interpretive traditions that give a sense of the wide-ranging ways in which this book has been read and understood through the centuries. In particular, it highlights that while specific questions and issues related to Hosea have persisted through the years, the underlying interpretive assumptions and approaches to these questions have shifted considerably in various historical periods, which in turn has led to considerable diversity in the reception of this prophetic text.
\end{abstract}

Keywords: Hosea; Gomer; Hebrew prophets; reception history; history of interpretation; Judaism; Christianity; feminist interpretation; form criticism

\section{Introduction}

In the preface to his commentary on the book of Hosea, the church father Jerome (d. $420 \mathrm{CE}$ ) begins not with praise for the prophet, nor with a reminder of the significance of the prophetic message. Rather, Jerome starts with an extended reflection of the various challenges this book poses for its readers. "If, in interpreting all the prophets, we need the advent of the Holy Spirit," he says, " .. how much more, in interpreting the prophet Hosea, must we pray the Lord and say with Peter, 'Expound to us this parable'" (Jerome 2017, p. 148). ${ }^{1}$ Indeed, Jerome continues, this complexity is highlighted by the final verse of the book, which asks, "Who is wise, and who can understand these things?" (Hos 14:10). These initial comments from Jerome point to the challenge of interpreting the figurative and metaphorical dimensions of the book, particularly the command given to Hosea to marry a promiscuous woman as a sign of Israel's unfaithfulness. But this leads to further ethical and moral issues for Jerome: "who would not be immediately scandalized at the beginning of the book and say: Hosea, the first of all the prophets, is commanded to take a prostitute as a wife, and he does not protest? He does not even feign unwillingness ... does not wrinkle his forehead, does not witness to his grief by growing pale, does not show his shame by blushing, but proceeds to the brothel and leads a whore to his bed" (Jerome 2017, p. 148).

While many disagree with the particulars of Jerome's reading, his general unease and apprehension as to how to proceed is common in the reception of Hosea. From antiquity, readers have struggled with historical, literary, ethical, and theological aspects of this first 
book of the Minor Prophets, driven in large part by the opening three chapters of the book and their purported recounting of the prophet's domestic life. This article examines a number of these issues, exploring how readers through the centuries have engaged with the interpretive challenges found in Hosea 1-3. In particular, the essay explores (1) debates concerning whether the marriage of Hosea and Gomer should be understood literally or figuratively; (2) questions concerning the identity of the woman in chp. 3 in relation to the events of chp. 1; (3) proposals on how to understand the metaphorical elements related to Hosea's marriage and Israel's infidelity; (4) ethical, theological, and rhetorical concerns raised by these chapters, including feminist critiques; (5) the place of Gomer's children in the opening chapter of the book; (6) the themes and rhetoric of chp. 2, including the punishment and wooing of the wife and Israel; and (7) the role of Hos 1-3 in Jewish and Christian liturgical traditions.

Although a number of studies have explored various aspects of the reception of Hosea $1-3$, these are often quite specific in either their subject matter or the timeframe being investigated (Rowley 1956; Kelle 2009); no recent attempt has been made to track the reception of these chapters from antiquity to the contemporary period. This exploration of the reception of Hos 1-3 attempts to rectify this by offering soundings from across historical, religious, and interpretive traditions that give a sense of the wide-ranging ways in which this book has been read and understood through the centuries. While not exhaustive, it highlights a number of contentious issues that have captured the imagination of readers from antiquity to the present day: from how one should understand the description of Gomer as a woman of promiscuity, to how the book's metaphorical dimensions should be interpreted, to what this account says about the text's central characters-God, the prophet, the woman, the children, and Israel. The readers and interpreters outlined in what follows demonstrate that while specific questions and issues related to Hosea have persisted through the years, the underlying interpretive assumptions and approaches to these questions have shifted considerably in various historical periods, which in turn has led to considerable diversity in the reception of this prophetic text.

\section{Hosea's Marriage and Gomer's Infidelity: Literal or Figurative?}

The book of Hosea locates the prophet in the eighth century BCE in the northern kingdom of Israel, during the reigns of the Judean kings Uzziah, Jotham, Ahaz, and Hezekiah, as well as that of Jeroboam II in Israel. ${ }^{2}$ In Hos 1, the Lord commands Hosea to take a wife of promiscuity (זנונים) ${ }^{3}$ and to have children of promiscuity, "for the land commits great whoredom by forsaking the Lord" (Hos 1:2; NRSV). ${ }^{4}$ Hosea marries Gomer daughter of Diblaim (v. 3), and they have three children: Jezreel, Lo-Ruhamah ("not loved"), and Lo-Ammi ("not my people"). It is clear from the beginning of this account that there is a symbolic element to the marriage (1:2). The question remains, however: were the marriage and the infidelity to be understood literally, or is this to be understood as figurative in nature? Readers have struggled with this question from antiquity, with both literal and figurative approaches common in Jewish and Christian traditions (Bitter 1975). As Kelle notes, "Although nearly all scholars acknowledge the paucity of historical and biographical details given in the book, the majority have not taken this as a deterrent from engaging in extensive speculation" (Kelle 2009, p. 187).

In parts of rabbinic and the medieval commentary traditions of Judaism, the command to take an unfaithful wife was understood as a literal injunction given to Hosea, which he took up in order to highlight Israel's unfaithfulness. Following the rabbis, Rashi comments that Hosea's marriage "is to be explained according to its apparent meaning" (Rosenberg 1986, p. 4). ${ }^{5}$ One particular reading that Rashi draws from is found in the Babylonian Talmud, where this divine command is understood as having a controversial backstory:

The Holy One, Blessed be He, said to Hosea: Your sons, the Jewish people, have sinned. Hosea should have said to God in response: But they are Your sons; they are the sons of Your beloved ones, the sons of Abraham, Isaac, and Jacob. Extend Your mercy over them. Not only did he fail to say that, but instead he said before 
Him: Master of the Universe, the entire world is Yours; since Israel has sinned, exchange them for another nation. The Holy One, Blessed be He, said: What shall I do to this Elder who does not know how to defend Israel? I will say to him: Go and take a prostitute and bear for yourself children of prostitution. And after that I will say to him: Send her away from before you. If he is able to send her away, I will also send away the Jewish people. This deliberation provides the background of the opening prophecy in Hosea ...

After two sons and one daughter had been born to him, the Holy One, Blessed be He, said to Hosea: Shouldn't you have learned from the example of your master Moses, who, once I spoke with him, separated from his wife? You too, separate yourself from your wife. He said to him: Master of the Universe, I have sons from her and I am unable to dismiss her or to divorce her. In response to Hosea's show of loyalty to his family, the Holy One, Blessed be He, rebuked him and said to him: Just as you, whose wife is a prostitute and your children from her are children of prostitution, and you do not even know if they are yours or if they are children of other men, despite this, you are still attached to them and will not forsake them, so too, I am still attached to the Jewish people, who are My sons, the sons of My faithful who withstood ordeals, the sons of Abraham, Isaac, and Jacob. (b. Pesachim $87 \mathrm{a}-\mathrm{b})^{6}$

The Targum, on the other hand, interprets this entire narrative account as figurativein the Aramaic, the marriage and children are removed entirely, and Hosea is commanded to help turn the unfaithful back to God. The Targumic tradition rewrites the text in a more palatable fashion, and the issue to which the metaphor points becomes the main subject matter. We see this in 1:2, which reads: "the Lord said to Hosea, "Go, speak a prophecy against the inhabitants of the idolatrous city, who continue to sin. For the inhabitants of the land surely go astray from the worship of the Lord" (Cathcart and Gordon 1989, p. 29). Later Jewish interpreters would take similar approaches. Ibn Ezra, Radak, and Maimonides, for example, suggest that this is a prophetic vision, and Hosea receives this command in a dream only (Rosenberg 1986, p. 4).

We find similar interpretive trajectories at work in the Christian tradition. Cyril of Alexandria, for example, pushes back against those (such as Origen) who want to read these verses in a figurative manner only, and who claim a prophet would never act in such a manner as depicted in the text. Cyril instead praises Hosea's obedience: "He takes Gomer, not acting out of lustful passion, but discharging a task of obedience and service" (Cyril of Alexandria 2007, p. 45; cf. Julian of Eclanum 2021, p. 110). Theodore of Mopsuestia indicates that the reference to Gomer's father (Gomer, daughter of Diblaim) is given "lest what was said should seem some trifling fiction and not a true record of events" (Theodore of Mopsuestia 2004, p. 40). A common interpretive move in early Christianity was to understand the marriage and its infidelity as literal, while also highlighting various elements of the figurative nature of the relationship-and these readings often have a Christological perspective. Irenaeus points out that just as the woman was made holy through her marriage to the prophet, so the church is made holy through union with the Son (Against Heresies 4.20.12; cited in Ferreiro 2003, p. 3). According to Theodore of Mopsuestia, the marriage is not only a teaching opportunity for Hosea in his ministry, but is also an example of divine condescension (Theodore of Mopsuestia 2004, p. 41). Jerome understands the marriage as literal, but also sees in this story the relationship of Jesus and the church, as well as a prefiguration of Jesus' engagement with sinful women, including the one who washed his feet (Jerome 2017, pp. 151-54).

In the medieval period, the question of Hosea's marriage would remain a lively one among Christian readers. In the Glossa Ordinaria, both the literal and figurative readings of the relationship are noted, and in his Summa Theologiae, Thomas Aquinas assumes the marriage relationship has some basis in reality (Aquinas [1485] 1920). ${ }^{7}$ However, the literal understanding of the marriage, particularly the infidelity, became unfashionable in the Reformation period. Luther, for example, speculates that Hosea was married, but that his 
wife did not actually act as a harlot; rather, Gomer allows these descriptors for herself and her children for the sake of the message:

Here people stir up big questions on account of that harlotry, whether the prophet committed fornication by the dispensation of God or took a harlot as wife. What some people say does not satisfy me, not even the words of Jerome. By their names the sons signify below what sort of people the Israelites are going to be. I think we must say the same thing about the harlot, because she was called a "wife of harlotry" to signify that the people now were committing harlotry and would do the same by forsaking God in the future.... Do not take this to mean, then, that harlotry is charged to the wife, that is, do not take this in the active sense, but understand that the wife has allowed herself, her sons, and her husband to be so named because of the people and against the people, as if she were saying: "I am called a harlot and my husband is called a whoremonger because you are harlots and whoremongers." Oh, how great a cross they suffered with those insulting names for the sake of the Word of God! (Luther [1556] 1975, p. 4)

Calvin likewise pushes back against Jerome and Aquinas and suggests that this is stagecraft, with Hosea assuming a character:

When, therefore, the prophet began to teach, he commenced somewhat in this way: "The Lord places me here as on a stage, to make known to you that I have married a wife, a wife habituated to adulteries and whoredoms, and that I have begotten children by her." The whole people knew that he had done no such thing; but the Prophet spake thus in order to set before their eyes a vivid representation. (Calvin [1559] 1846, p. 45)

The eighteenth-century Baptist John Gill notes that Hosea is commanded to "take thee a wife of whoredoms ... a notorious strumpet". However, Gill notes, this appears to be "countenancing whoredom," while also being "very dishonourable to the prophet." He thus prefers, following the Targum, to understand this as a parable (Gill 1763).

Over time, these misgivings would give way again to more literal understandings of the marriage and the infidelity. In the nineteenth century, Pusey notes that the text uses the plural form of the term זנונים, which points to the ongoing nature of the woman's unfaithful activity: "She must ... have been repeatedly guilty of that sin, perhaps as an idolatress, thinking of it to be in honour of their foul gods" (Pusey 1885, p. 20). Pusey's reading suggests that Gomer's infidelity might be connected to ritual sexual activity connected to the cult, an idea that would become popular in the twentieth century (more on this, below, in the discussion on the marriage metaphor). Modern readers also became interested in the question of when Hosea became aware of his wife's misdeeds: did he know beforehand, or was her unfaithfulness after the marriage had taken place? Wellhausen (1892) suggests the latter, and argues that Hosea did not know of her unfaithfulness prior to their marriage, an idea that would be followed by a number of other readers (Harper 1905; Andersen and Freedman 1980; Macintosh 1997). In his study on Hosea's marriage, Rowley (1956) comes to the opposite conclusion - that the unfaithfulness took place prior to the marriage-which strengthened the message to Israel concerning God's fidelity to an unfaithful people: both God and Hosea were aware of the great task in front of them.

Historical reconstructions have remained popular in late-modern readings, with many significant commentaries suggesting that the historical prophet had a marriage where there was some form of infidelity (see, e.g., Macintosh 1997). However, in the latter parts of the twentieth and early twenty-first centuries, academic studies began focusing on rhetorical elements of the text, eschewing almost all attempts at biographical reconstruction (Landy 1995; Ben Zvi 2005; Bos 2013). If the prophet is a later literary creation, so too is the depiction of his marriage. Instead, focus has shifted to literary, rhetorical, and ideological concerns in the study of Hosea (more on this below).

In summary, readers have long wrestled with how to understand the nature of the marriage and the infidelity depicted in Hos 1 . Both literal and figurative readings of the 
text have been common throughout history, and indeed across interpretive traditions. As we will see, questions closely related to the reality of the marriage and its infidelity include how one should make sense of the metaphorical nature of the marriage, as well as how readers should understand and respond to the challenging ethical and theological issues in the text-issues to which we return below.

\section{A One-Woman Man? The Relationship of Hosea 1 and 3}

The questions concerning the relationship of Hosea and Gomer are not restricted to chp. 1. In Hos 3, the prophet is instructed by God to "Go, love a woman who has a lover and is an adulteress, just as the LORD loves the people of Israel" (3:1). A recurring question has been how this command relates to what has already been relayed. Do these verses again refer to Hosea and Gomer, or is another woman in view? This confusion is evident already in the major versions, a point often noted by interpreters (see Ewald [1840] 1875, pp. 245-46). Should the initial clause-which is ambiguous in the Hebrew-be rendered as "The LORD spoke to me again, 'Go ... '" (Targum), or "The LORD spoke to me, 'Go, again, and love... '" (LXX; Vulgate)?

As was the case with chp. 1, there are some traditions that interpret this scene figuratively, and so the identity of the woman is left unexplored. The Targum, for example, continues its figurative reading that erases all reference to an actual woman: "Go and speak a prophecy concerning the house of Israel, who are like a woman loved by her husband, but she betrays them" (Cathcart and Gordon 1989, p. 35). A number of church fathers also gloss over the identity of the woman and instead highlight the symbolic reference with which the text is concerned, namely Israel (Jerome 2017) or Judah (Theodore of Mopsuestia 2004). Some later readers have suggested that while the account of chp. 1 is based on historical circumstance, chp. 3 is allegorical or a secondary addition, and so cannot be related to the prophet's life (Volz 1898; Batten 1929).

Another approach understands chp. 3 as introducing a second woman. This reading also has ancient roots in both Jewish (Ibn Ezra; R Joseph Kara) and Christian traditions (Cyril of Alexandria; Luther, though the latter believes the account to be figural). In many of these readings, it is assumed that Hosea purchases a prostitute after the failure of his first marriage with Gomer (Gill 1763; Rudolph 1966; Sweeney 2000).

The majority of readers, nevertheless, have assumed that this account refers to Hosea and his wife Gomer. Within this interpretive approach, some see chp. 3 as a first-person retelling of the events from Hosea 1 (Ambrose, Letter 50 [cited in Ferreiro 2003]; Calvin [1559] 1846; Gordis 1954). Macintosh (1997, pp. 113-17) suggests that chp. 3 was in fact the earliest account from Hosea's own perspective, with chp. 1 a later retelling. However, most interpret this as a subsequent scene between Hosea and Gomer. ${ }^{8}$ In this reading, "Gomer was an originally faithful bride, who subsequently committed adultery, underwent divorce and perhaps descent into slavery, but was eventually taken back by Hosea as a symbol of Yahweh's love for apostate Israel" (Kelle 2009, p. 190).

Various other readings have also been put forward. Rudolph asserts that original command to Hosea was to marry a woman and have children with her, giving them symbolic names; the reference to a promiscuous wife was added later as the first three chapters were brought together (Rudolph 1966). Another reading suggests that the same woman is in view, but that chp. 1 refers to a time when Hosea was a client of Gomer's, while chp. 3 refers to Hosea purchasing and marrying Gomer for his wife (Davies 1992, pp. 108-9).

There are, then, a variety of ways in which readers have made sense of the relationship of chp. 3 with chp. 1, including figurative approaches, readings which suggest a new woman is in view, and those which posit that this chapter also relates to Gomer in some way. 


\section{Hosea's Metaphor(s) and Their Meaning(s)}

Although there is disagreement on the historical reality of Hosea's marriage, it is clear that there is a figurative dimension to the union. In 1:2 the reason given by God to Hosea for the marriage is that "the land commits great whoredom by forsaking the Lord." What is the symbolic significance of Hosea's marriage, and how does this relate to the rest of the book? Again, there have been a variety of approaches to this issue.

From antiquity a common understanding has been that Hosea's message was broadly concerned with idolatry and religious infidelity on the part of the Israelites. As such, the call to return to $\mathrm{YHWH}$ is an invitation to return to a commitment to God and his ways, and a turn away from idolatry and pagan influences, particularly in relation to the northern kingdom. Cyril of Alexandria's comment on Ephraim and the northern kingdom is illustrative: "they cut their ties not only with Jerusalem but also with the very worship of God, bowing down to golden heifers, giving sacrifices and worship to 'the works of their hands'" (Cyril of Alexandria 2007, p. 31). This broad focus on Israel's religious apostasy is found often in the reception of Hosea, across interpretive traditions (see, e.g., Targum; Jerome; Rashi; Calvin).

Over time, this religious framing has been refined and revisited. Form-critical scholars in the twentieth century began to focus on identifying the infidelity referred to in the second half of v. 2. A common interpretation was that this national "whoredom" related in some way to a sexualized Baal cult in eighth century Israel (May 1932; von Rad [1967] 1968), and that Gomer herself may have been engaged in a sexualized Baal fertility cult, or served as a cultic prostitute. Wolff subscribes to the former; in his reading, Hosea was called to take a woman who was involved in the sex cult in ancient Israel. Wolff claims that a Canaanite sexual rite had made inroads into Israel's religious practices, whereby "young virgins offered themselves to the divinity and expected fertility in return" (Wolff 1974, p. 14). A young woman would have sexual relations with a stranger, normally once in their lifetime, though it could be repeated, as part of cultic activity. This was a practice thought to have roots in other ancient traditions, as noted by Herodotus. Thus, Hosea's "wife of promiscuity"

refers to any young woman ready for marriage ... who had submitted to the bridal rites of initiation then current in Israel ... she whom Hosea is to marry is therefore not an especially wicked exception; she is simply representative of her contemporaries in Israel.... Since the prophet is expected to take a "wife of whoredom," it becomes startingly clear to him and his people how complete Israel's corruption and guilt have become. (Wolff 1974, p. 15)

Another interpretation is offered by Mays, who sees Gomer as a sacred prostitute connected to Canaanite religious activity and Baal mythology:

[Baal] was the god of the late autumn and winter rain storms upon which the peasant farmer was utterly dependent for water, pasture, and crops. The believer thought of the land as the wife which the god fertilized with rain. The cult was based on sympathetic magic. To anticipate, induce, and participate in Baal's intercourse with earth, sexual rites were used, the hieros gamos celebrated in the cult by representative protagonists ... The cult of Baal involved both men and women in sexual rites; the men lay with sacred prostitutes, and the women as devotees of Baal possibly made themselves available to male worshippers to receive fertility through the cult. Here metaphor and reality are almost synonymous. It is this cultic environment which furnishes the key to the most likely interpretation of the two expressions "a woman/wife of harlotry" and "children of harlotry" ... Hosea was to select a woman who was recognizable as harlotrous in the sense of the word in his prophetic vocabulary ... A common prostitute would satisfy the public symbolism, but not as eloquently as one whose sexual promiscuity was a matter of the very harlotry of Israel in the cult of Baal. The more likely category is that of the sacred prostitutes. (Mays 1969, pp. 25-26) 
While these readings differ in the details, both assume that Gomer's "promiscuity" reflects not only religious infidelity, but also points to actual sexual practices that were part of Canaanite fertility rites that Israelites took part in, or which had been adopted by the Israelites as part of their own religious practices. While the sexual dimensions of this interpretation have fallen out of favour, the assumption that Hosea is critiquing Israelite engagement in Canaanite traditions, or syncretistic practices that combine Baal and YHWH worship, has remained popular (Andersen and Freedman 1980; Macintosh 1997). ${ }^{9}$

This connection of Hosea to a Baal cult would hold sway for much of the twentieth century, even if scholars became less sure over time of how confidently they could comment on the biographical dimensions or sexual elements of Hosea and his marriage (Jeremias 1983). Over time, however, the assumptions concerning sexually based cultic activity in ancient Israel would come in for particular critique, as scholars have increasingly questioned the existence of such activity (Fischer 1976; Bird 1989; Gruber 2017). ${ }^{10}$ Indeed, Keefe and others have argued that the assumption that a sexualized fertility cult is at the root of Hosea's concerns can be "traced to the biases of a theological agenda within which Canaanite religion is gendered as the seductive and degenerate 'other' against which biblical religion defines itself" (Keefe 1995, p. 72).

In recent decades, commentators have given increased attention to the metaphorical language and imagery in the book. In doing so, the dominant cultic framing of Hosea's critique has been challenged. Thus, readers have suggested that socio-economic (Keefe 2001) or political (Yee 2001; Kelle 2005) issues should be given more consideration as significant parts of Hosea's message, even if sexual imagery is used and religious apostasy may also be in view. Indeed, the marriage and sexual imagery is multi-layered and is used in diverse ways throughout Hosea, resisting any one-size-fits-all approach to the book and its metaphors (Moughtin-Mumby 2008).

\section{The Marriage and Infidelity: Ethical, Theological, and Rhetorical Concerns}

As noted above, readers have long disagreed on whether or not the marriage of Gomer and Hosea (or the infidelity within the relationship) should be understood in literal fashion. Nevertheless, within the traditions of Judaism and Christianity, the book and its message have long been understood as a reflection on repentance and return, as well as divine love and fidelity. We see this clearly in texts such as Maimonides' Mishneh Torah, where Hosea plays a key role in the section on "Repentance" (Sefer Madda, 7:6; cf. Sweeney 2000, p. 26). This understanding is also common in Christian tradition, from antiquity to the modern era (Jerome; Aquinas; Pusey). In this sense, while there has been disagreement on whether Hosea's marriage was a depiction of historical events, the fact that the marriage metaphor was employed in this way was not seen as problematic for much of history. Rather, the metaphor and indeed the book as a whole have long been understood as concerned with divine love and returning to YHWH.

This is not to say that early readers did not have ethical or moral concerns about the book and its message. A recurring issue addressed in Jewish tradition was whether or not God would actually ask one of his prophets to act in this way. As noted above, the Targum erases the woman and children altogether from the story, while influential commentators such as Ibn Ezra suggested that this was a vision, sidestepping the ethical quandaries of this divine request. For those who held that the marriage and/or its infidelity were in fact based in reality, it was noted that God at other times commands his servants to perform unusual acts, such as the actions of Ezekiel, and so this is not out of the ordinary-even if such commentators would not be encouraging others to follow in the prophet's footsteps (Malbim; Rosenberg 1986, p. 5).

Similar concerns were raised in Christianity, where Hosea's union led to considerable ethical and moral reflection regarding husband and wife. Several church fathers would go to great lengths to argue that the woman does not defile the prophet by association; rather, the prophet is to be applauded for "converting the prostitute to chastity" (Jerome 2017, p. 153; cf. Cyril of Alexandria 2007). On the other end of the spectrum, in his work 
On Modesty, Tertullian uses Hosea's marriage to a "base prostitute" as part of a catalogue that indicates why Jesus, and the new dispensation which he inaugurated, is a better moral guide for discipleship than is the Old Testament and its sordid stories (Ferreiro 2003, p. 3). Similar ideas are found in Didymus the Blind, who takes Hosea to task for not setting an appropriate example. These examples nothwithstanding, the apologetic tendency was strong: moving to the medieval period, Aquinas uses Hosea as part of the larger discourse on natural law in his Summa Theologica. To those who say that Hosea is an example that natural law can be changed-as the prophet took a wife of harlotry and so was associated with adultery-Aquinas answers that what is commanded by God is, by definition, right and natural (Aquinas [1485] 1920 [Prima Secundae Partis (I.II)Q 94, A 5]).

As discussed above, the Reformation period saw a shift back to figurative readings, in large part because of the ethical issues raised by God's command to Hosea. Luther, Calvin, Gill, and others find it inconceivable that God would ask Hosea to fulfil this command literally. The answer for these readers is to understand the text as depicting stagecraft or a vision. With the swing back to more literal understandings in the modern period, including those which assume a relationship to the Baal fertility cult, one detects little ethical or moral concern in the reception of Hosea-rather, the metaphor is seen as a fitting way to illustrate Israel's issues (Mays 1969).

Thus, for most of history, any ethical issues noted in the reception of Hosea focused on the implications of the text's portrayal of God or the prophet. This began to change in the twentieth century, as readers began to give more attention to Gomer and her children. A key issue here is not just how we understand the metaphor, but how we understand the nature and purpose of metaphor itself. Is symbolic representation simply a picture, or does it shape how we think? Are there larger and deeper implications to the metaphors that we use? On one hand, Philip J. Long writes that feminist and other approaches can be helpful for understanding Hosea, but "they often miss Hosea's point by getting bogged down in the sociological details of the metaphor. The key to understanding Hosea is the love which the Lord has for his nation" (Long 2013, p. 117).

Alternatively, Gale Yee notes,

Hosea's metaphor of the marriage between Yahweh and Israel gives an entrée into the divine-human relationship as no other metaphor can. It engages the reader in a compelling story about a God who is loving, forgiving, and compassionate, in spite of Israel's sinfulness. However, growing out of a social structure and value system that privileged the male over the female, this metaphor makes its theological point at the expense of real women and children who were and still are victims of sexual violence. When the metaphorical character of the biblical image is forgotten, a husband's physical abuse of his wife comes to be as justified as God's retribution against Israel. (Yee 1992, p. 200)

This quotation from Yee leads us to the most significant and influential development of the past half century in Hosea studies, which has been the rise of feminist readings of the book (Weems 1989; Brenner 1995; Yee 1996; Sherwood 1996; Baumann 2003). Along with exploring the book's marriage imagery, such studies have also examined the broader rhetoric of the text and its reception. Feminist readings have noted a number of issues that have often been overlooked in the history of interpretation.

First, the text is unequivocally androcentric. In the analogy with Israel, the male figure is equated with God, while the woman is equated with the sinful people. The book also critiques the woman's sexuality, while leaving the man's uninterrogated-a significant double standard noted by feminist readers. This is problematic on a number of levels, not least of which is that it perpetuates androcentric perspectives. As Julia O'Brien notes, "Reading with and for the male protagonist of the texts makes it "work": readers accept his feelings as justified and his desire for revenge (even if not its actualization) as understandable. Readers consider a woman's choice of multiple partners as whoredom and her husband's willingness to forgive her as magnanimous only when they assent to the patriarchal assumptions on which the metaphor depends" (O'Brien 2008, p. 67). 
Noting the male gaze and objectification of female sexuality in Hosea, Setel (1985) famously described the imagery of Hosea as pornographic. As Yee asks, "if Hosea had been a woman, commanded to marry a promiscuous man, what form would her prophecy have taken? In what would her tragedy consist? What kinds of personal grief, disappointments, or sorrows would she experience?" (Yee 1996, p. 220).

Related, the woman has little agency and no voice in the text. God or the husband are always speaking on her behalf. Sherwood notes, "The claim that patriarchy dispossesses women of language, speech and a voice is perfectly demonstrated in a text that obstinately refuses to allow woman the right to self-expression" (Sherwood 1996, p. 300). Further, as the text unfolds we encounter threats of violence and shaming of the woman in chp. 2, scenes that are all too common for too many women. ${ }^{11}$ For some, the reconciliation comes too soon with too little thought for the woman (Weems 1989). Taken together, feminist interpreters have argued that Hosea is not the divine love story that it is often made out to be, and have encouraged readers to examine the suppositions that underlie the book's imagery.

Within this, critiques of Hosea from feminist perspectives are diverse and wideranging (for discussion and critique of various feminist readings, see Sherwood 1996; Keefe 2001; and O'Brien 2008). A few prominent approaches can be summarized in this way:

1. One approach highlights the problematic nature of the text, while attempting to hold on to its place as Scripture (Weems 1989; Yee 1996). Such readings approve of the underlying message of divine love and repentance, but criticise the vehicle (i.e., the marriage metaphor) as inappropriate (see discussion in Sherwood 1996).

2. Other feminist readings have focused on the interrelationship of the text and its reception. Thus, one interpretive stream re-examines the metaphor from a materialistic perspective, suggesting that the marriage and sexual imagery of Hosea have been misconstrued because of social and theological biases; closer examination reveals that the prophet is ultimately offering a critique of social, economic, and political issues, but the patriarchal nature of the text's interpreters has kept the focus on sexual matters (Keefe 2001; Yee 2001). A related approach focuses on the fact that men were likely the primary intended hearers of this text-in which case they were to identify themselves with the unfaithful woman (Leith 1989). This "feminizing" of the male audience is often missed in the interpretive traditions. "To call the people of God 'woman', and even more disturbingly 'promiscuous woman', is, in a patriarchal context, to give offence ... In resisting identification with the woman, androcentric commentators support the ideology of the text but resist its symbolic roles" (Sherwood 1996, pp. 263-64).

3. One further approach is worth noting, as it offers a feminist reading but from a very different perspective. Wacker and others see in Gomer a subversive, powerful figure, who may even be a symbol of (repressed) goddess worship in ancient Israel (Wacker 1996, 2012; Balz-Cochois 1982). These readings try to liberate the woman in the text from traditional interpretations, while assigning some agency and power to the character, drawing on ANE traditions.

In spite of these different approaches and perspectives, a clear trajectory can be identified as readers have begun noting the problematic rhetoric of the portrayal of the woman in Hos 1, and indeed the broader context of chs. 1-3-it is biased in its portrayal of the woman, and dangerous in the perspective which it espouses. As we shall see, many of these same issues have been raised in relation to the book's portrayal of the children.

\section{Gomer's Children}

Another important dimension of the opening chapters of Hosea relates to the children, who are often overlooked because of the scandalous nature of the marriage. The children of Hosea and Gomer are introduced in 1:2 even before their births-along with taking a wife of promiscuity, Hosea is told to have "children of promiscuity" (וילדי זננים) (1:2). Those who argue for figurative interpretations of the marriage offer similar accounts of the children. 
Calvin, for example, notes that if Hosea did not really marry a harlot, neither did he have children with her (Calvin [1559] 1846, p. 34). Pusey (1885) offers an opposing view: if Scripture relates these events as having happened, then we must take them as such (see also Ewald [1840] 1875, p. 235). Just as Jesus was the "friend of publicans," so Hosea's family does not detract from his message or status. For Pusey, the mere presence of these children among the people means that they, too, were vehicles of the prophet's message, even if only through their names (Pusey 1885, p. 21; cf. Mays 1969, p. 27). ${ }^{12}$

The phrase "children of promiscuity" has been understood in various ways. Jerome comments that the term can mean either that Hosea took in the woman's previous children born from promiscuity, or that the prophet would have children with the woman who would nonetheless carry a label similar to their mother (153). Isho' dad of Merv understands this as indicating that the children will follow in the mother's footsteps (Ferreiro 2003, p. 3). Pusey notes that the children, even though Hosea's, share the mother's description, because in some way sin is passed down from generation to generation (Pusey 1885, p. 20). Wolff proposes that these are "children of whoredom" because their mother was involved in Canaanite sexual rites, thus "they owe their existence to a pagan god" (Wolff 1974, p. 15).

Gomer gives birth to a son, and we are told that she bears this child for Hosea (1:3). With the subsequent children, however, no mention is made of the prophet. Thus, some readers have inferred that this first child was Hosea's, while the second and third were the fruits of Gomer's infidelity (Rowley 1956). Hosea is commanded to name this son Jezreel, because the house of Jehu will be punished for the blood of Jezreel (v. 4). The use of the name Jezreel has been interpreted in various ways. The Targum continues its figural reading, removing any reference to the birth of the son and replacing the name Jezreel with "the scattered ones," playing on the Hebrew root indicating seed or sowing (זרה) (Cathcart and Gordon 1989, p. 29). Other Jewish readers would offer more specific interpretations, including those that equate the son with Jeroboam (Radak) or the generation which followed him (Ibn Ezra; see Rosenberg 1986, p. 5). Noting that the name Jezreel is related to "sowing," Cyril comments that the relationship of Hosea, Gomer, and Jezreel is similar to that between Moses, Israel, and Christ: a prophet is called to lead a wayward people, culminating in the "seed of God," the true first son (Cyril of Alexandria 2007, pp. 50-51). Citing the similarity between the names "Jezreel" and "Israel," Calvin ascribes the following to God: "They call themselves Israelites; but I will show, by a little change in the word, that they are degenerate and spurious, for they are Jezreelites rather than Israelites". For Calvin, this indicates that the northern kingdom "could no longer be deemed as including the race of Abraham" (Calvin [1559] 1846, p. 34).

The reference to the house of Jehu and the blood of Jezreel has also been interpreted variously in the traditions. This clause is most frequently understood as related in some way to the events of $2 \mathrm{Kgs} 9-10$, where Jehu slays Ahab at Jezreel. A difficulty, however, is that 2 Kings suggests that Jehu's actions were supported by Elisha, and, thus, by God. How do we reconcile this with the "blood of Jezreel"? Andersen and Freedman hold a minority view: they see Hosea's critique as aimed at the Omride dynasty, rather than at Jehu. "Hosea is saying that what God did to Ahab and his brood by means of Jehu is exactly what he will now do to Jeroboam and his family, and for similar reasons ... Hosea thinks that Jeroboam is following in Ahab's footsteps" (Andersen and Freedman 1980, p. 181; italics in original). A more popular reading, however, has been that the blood of Jezreel refers to the blood of Ahab, and is a critique of Jehu and his actions. ${ }^{13}$ A number of readers overcome the interpretive obstacle of Jehu's divinely-ordered conduct by doubting Jehu's sincerity, suggesting that his motivations were for his own gain rather than divine obedience (Cyril of Alexandria 2007; Gill 1763; Ewald [1840] 1875; Pusey 1885; Wellhausen 1892). Calvin attempts to resolve this issue by noting that it was the short-lived nature of Jehu's reformation to which the prophet refers-and, with a contemporary allusion, he illustrates this with reference to the short-lived zeal for religious reform likewise found "under Henry King of England" (Calvin [1559] 1846, p. 35; cf. Mays 1969, p. 28). In a similar reading, Wolff suggests that the blame pointed at Jehu could point to the fact that he did 
not resist the "Canaanization" of Israel's religion during his reign. "Hosea's first child, named Jezreel, is to be a constant reminder that the reigning dynasty-from the hour of its founding onward-is not in accordance with God's will. A monarchy in Israel that bases its power upon bloodletting can expect a "No" from Yahweh" (Wolff 1974, p. 18). Sweeney expounds on some of the theological implications of this intertextual link between Hosea and 2 Kings: while we often think of Israel's prophets (and, indeed, the broader corpus of the $\mathrm{HB}$ ) as having a unified theological viewpoint, in fact there is great diversity with regard to interpreting the divine will-Hosea's disagreement with other traditions concerning Jehu is a case in point (Sweeney 2000, pp. 17-18).

Gomer, we are informed in v. 6, next bears a daughter who is to be named Lo-ruhamah ("no pity;" Vulgate: "without mercy"). This is because God will no longer have pity on or forgive Israel. The term ruhamah means much more than pity, as commentators often note; it also implies love, particularly the tenderness of a parent to a child (Pusey 1885; Mays 1969; Wolff 1974). In rabbinic tradition, the mention of a daughter was seen as referring to the weaker generations that followed Jeroboam, in particular Zechariah, who was on the throne for only six months (Radak; cf. John Gill). Rather than pointing to an individual, Rashi and Ibn Ezra see in this language a prediction of coming judgement, including the coming exile (so too Cyril of Alexandria 2007; Gill 1763). In the same vein, others have noted the distinct change in relationship which this name implies. Calvin, for example, comments that divine favour has been removed from the people-the election freely given has been taken away (39). Sweeney (2000) similarly notes that this is a significant change in relationship, from care under the God who is known for showing mercy to his people (e.g., Exod 34:6) to a state where such mercy will now be withheld. ${ }^{14}$

The final verses of the chapter introduce one further child. After weaning Lo-ruhamah, Gomer bears another son, this one to be named Lo-ammi, "not my people". The Targum renders both elements here figuratively - the weaning refers to the generation that will pass away while in exile, and the reference to a further son indicates that the people continued on in their evil ways, forsaking the Torah (Cathcart and Gordon 1989, p. 30; cf. Ibn Ezra; Malbim). Rashi, however, states that the plain meaning of the text is the best reading: Hosea's wife bore another son.

The naming of the third child "not my people," according to Theodore of Mopsuestia, refers not to a person, but to coming trouble at the hands of foreigners (Theodore of Mopsuestia 2004, p. 43). Cyril offers both a literal and a figurative reading: the historical meaning of the text refers to when the people were carried off by the Assyrians. The spiritual meaning refers to the Jewish people who, rejecting Jesus, forfeited their status as the chosen people-and in Cyril's view the church has assumed this place (Cyril of Alexandria 2007, pp. 57-58). A similar interpretation is offered by Luther, who sees here a connection of "the prophecy of the temporal kingdom with that of the eternal kingdom" (Luther [1556] 1975, p. 6), and a firm rejection of the synagogue. Both Cyril and Luther employ strong supersessionist language in their comments on these verses. Calvin uses less inflamed rhetoric, but a similar idea, noting that "not my people" indicates the Jewish people would essentially now be no different from profane Gentiles (Calvin [1559] 1846, p. 47).

The increasing chastisement involved in the names of the children is noted by several commentators (Yee 1996, p. 219). Pusey writes, "As the scattering of God did not involve the being wholly unpitied; so neither did the being wholly unpitied for the time involve the being wholly rejected, so as to be no more His people" (Pusey 1885, p. 24). This negation of a key aspect of Israel's identity in the HB_-עמי, "my people" (Exod 6:7; Lev 26:12; Jer $7: 23$ ) - has been the subject of frequent comment. For Mays, this suggests that the negative consequences related to the covenant relationship will now come into effect (Mays 1969, p. 29).

A key interpretive issue related to the children has been how these characters should be identified in relation to the larger metaphor. This is particularly acute in Hos 2:1 [Heb. 2:3], where the frame of reference shifts to brother Ammi and sister Ruhamah, and they are 
asked to engage with their mother. If the husband is God and the wife is wayward Israel, who do the children represent in this symbolic world? Luther takes the entirety of chp. 2 as addressed to both Jews and Christians who have received mercy, while the mother refers to the Jewish people ("the synagogue") more broadly (Luther [1556] 1975, p. 8; cf. Pusey 1885, p. 28). Gill (1763) suggests that the reference to Ammi and Ruhamah can refer either to Judah and Benjamin, who are to speak to wayward Israel, or to the faithful among the ten tribes. Wellhausen follows this latter idea: individuals are here asked to oppose the wrong direction of the larger whole, represented by the mother (Wellhausen 1892, p. 98; cf. Mays 1969, p. 36). Nevertheless, the symbolism of the family is not always clear, and the metaphors used are complicated and at times contradictory (see Moughtin-Mumby 2008; cf. Landy 1995).

Contemporary readers have highlighted a number of concerning issues that arise in these opening chapters of Hosea when the text is read from the perspectives of the mother and children. For example, while God is in communication with Hosea about the children and their future, Gomer remains without agency—bearing and sustaining the offspring, she nevertheless has no voice in the conversation regarding their names or their futures. Wacker suggests that the feud in the text is really between Gomer and YHWH: "Do the children belong to the side of Gomer, the 'êšet zĕnûnîm, who brings them into the world and nourishes them, or to the side of God, who gives them calamitous names and declares them to be living metaphors of the wicked Israel?" (Wacker 2012, p. 372). Landy likewise comments, "It must have been difficult to be married to Hosea. Gomer tries to keep the family together, while he insists on calling the children horrible names, on excoriating her as an example of Israel's infidelity" (Landy 1995, p. 23). These readings are a reminder of the androcentric perspective of the text, and these issues come into sharper focus in chp. 2, where the "rehabilitation" of the children and their mother is envisaged.

\section{Repentance and Divine Love? Reading Hosea 2}

The first three chapters of Hosea are often read as a unit, with chp. 2 presented as one long speech and interpreted as an explanation of the figurative elements at work in the more biographical sections of chs. 1 and 3. Chapter 2 moves back and forth between references to the woman and children and to what are obviously more social, religious, and land-related references. In doing so, it offers what seems to be an explanation of the failed relationship, and how God will both punish and woo back the unfaithful partner. In what follows I highlight several themes and images in this chapter that have been picked up in diverse ways in the reception of Hosea; as we will see, this chapter, too, has been used to argue for a historical reconstruction of Hosea's marriage, as a theological call to return and repentance, and as a basis for rhetorical and ideological re-reading.

\subsection{The Children and Divorce: $2: 1-2$}

In Hos 2:1 [Heb 2:3], ${ }^{15}$ the frame of reference shifts to brother Ammi and sister Ruhamah-here the negative particle attached to the names in chapter 1 has been removed. These siblings are to plead with their mother "for she is not my wife, and I am not her husband" (2:2). The call for the children to plead with their mother has been understood variously. In the modern era, commentators began to note the similarities in language and style with courtroom and legal matters. Of particular importance here is the Hebrew term ריב, often translated as "plead with." This term is more confrontational and hostile than "plea" would seem to indicate, and other suggested translations have included "accuse" or "argue with" (Andersen and Freedman 1980, p. 219; cf. Vulgate: "judge").

The use of the term רas led to some speculation that this section may have originated as part of legal proceedings-giving credence to the fact that a real marriage may have been in view. Indeed, the language of the subsequent clause in 2:2 ("for she is not my wife, and I am not her husband") has led to similar conjecture (see discussion in Kelle 2005 , 2009). By the eighteenth century John Gill was suggesting that these verses indicate an official bill of divorce. This notion would gain momentum in the ensuing centuries, 
as further ANE texts and traditions-and thus potential parallels-were discovered. In the twentieth century, a number of scholars were confident that this statement reflected an actual divorce formula, as seen in other ANE texts such as those from Elephantine (Gordon 1936; de Vaux 1961). Over time this assuredness faded; while some relationship to divorce might be in view, the notion of a technical declaration of divorce fell out of fashion by the late twentieth century (Wolff 1974, p. 33; Andersen and Freedman 1980, pp. 222-23).

The children are to plead with their mother to "put away her whoring from her face, and her adultery from between her breasts" (2:2). The allusion to the face and breasts has most often been understood as a reference to the custom of prostitutes making up their faces and perfuming themselves for their lovers (Radak; Nicholas of Lyra; Calvin; Gill). Various figurative readings have also been put forward. Malbim suggests the harlotries of the face may refer to flagrant idolatry, while those of the breast refer to those practices done in secret (Rosenberg 1986, p. 10). Early Christian writers understood the removal of the harlotry and the adultery as referring to Israel's removal into captivity, at which point the unfaithfulness and idolatry would be rooted out (Theodore of Mopsuestia 2004, p. 46; Cyril of Alexandria 2007, pp. 65-67; Nicholas of Lyra 1603). Calvin comments that while the reference to the face and breasts alludes to the "meretricious finery" of harlots, it is the shamelessness of the people in their apostasy that is in view (Calvin [1559] 1846, p. 62). With the rise of modernity, readers began to focus in on the exact nature of the infidelity in question. For many, this betrayal refers to Israel's worship and religious life, specifically Baal worship-not least because Baal is mentioned later in the chapter (2:17; so Wellhausen 1892, p. 97; Mays 1969, p. 36). Wolff goes so far as to say that the adornment of the wife's face and breasts may refer to jewellery worn as part of the Baal cult (Wolff 1974, pp. 33-34).

\subsection{Other Lovers (2:4-7) and Baal (2:8-9)}

The castigation of the woman continues in 2:4-9, focusing on the fact that she has chased after other lovers. The use of the term "lovers" to refer to adulterous lovers is found only in Hosea, Jeremiah, and Ezekiel. The identification of the lovers in Hos 2:5-7 has been the subject of wide-ranging commentary. In Jewish tradition, these lovers have been understood as idol worship (Targum; Abarbanel), or having to do with following after foreign nations (Rashi; Radak; see Rosenberg 1986, p. 11). These same options are found in the Christian tradition as well: Jerome notes that the literal sense refers to Israel's engagement with the Assyrians, Babylonians, and Egyptians (Jerome 2017, p. 161), while Calvin sees these lovers as false gods (Calvin [1559] 1846, p. 67).

In the modern era, the focus of interpretation shifted to the presumed cultic and agricultural elements at work of these verses. A key element here is that the lovers are said to give the woman "my bread and my water, my wool and my flax, my oil and my drink" (2:5). Many modern readers have taken this to indicate an assumption that life's material blessings come from these lovers, that is, false gods (Ewald [1840] 1875, p. 240). Indeed, a common interpretation has been that this relates to the land-focused Canaanite cult-it is Baal that is providing Israel's sustenance (Wellhausen 1892, p. 98; Mays 1969, p. 39; Wolff 1974, p. 35). However, the identity of these lovers is not made clear; in fact, the only explicit identification of lovers in Hosea comes in chp. 8, where the text refers to the lovers as those nations with whom Ephraim has made treaties. Thus, an alternative reading is that these lovers should be understood as foreign nations. In this case, the supply of material goods - bread, water, wool — could refer to trade with these nations, and the assumption that provision comes from these other nations rather than being provided by Israel's God (Yee 2001, p. 376).

In 2:8 we have the first explicit mention of "Baal" in Hosea. Readers have made sense of the reference to "Baal" in different ways, a tradition that extends back at least to the Dead Sea Scrolls. Religious readings which see this as referring to religious infidelity and idolatry have been the norm in both the Jewish and Christian traditions, as well as in critical biblical scholarship. The Targum, for example, replaces the term Baal with "idols" (Cathcart and Gordon 1989, p. 32), while Jerome sees Baal as referring to the "demon of 
the Sidonians," or perhaps Bel of the Babylonians (Jerome 2017, pp. 162-63). However, in what is our oldest extant commentary on this text, the fragmentary Hosea Pesher (4QPHos a II:3-6) found at Qumran, we find a political reading of the Baalim. Israel's infidelity is interpreted as political promiscuity-Israel, the pesher states, went after and relied on foreign nations during Hosea's time, and so is chastised for blindly following these nations like gods (Ego et al. 2005). While fragmentary, this pesher seems to indicate that a reading which focused on the political elements of the Hosea account was acceptable and perhaps well known at Qumran.

Thus, the identity of the "lovers" and Baal in these verses has a more complicated history than we might imagine. Reading these as focused on idol worship or religious infidelity has been common, but this is not the only possible interpretation. Indeed, our earliest interpretation from the Qumran materials understands this as a reference to political issues, and this reading has been picked up by others throughout history (see Kelle 2005).

\subsection{Stripping and Wilderness (2:3), Hedging in (2:5-6), Uncovering (2:10-12)}

Beyond the castigation of the woman, Hos 2 also paints a picture of how God or the husband will respond to this infidelity. In 2:3 we read that if this mother figure does not change her ways, she will be stripped naked, laid bare like a wilderness. In 2:6, the husband vows to "hedge her way with thorns, and build a wall against her". In vv. 10-12, the speaker vows to uncover the woman's shame, as well as doing away with her feasts and festivals, and laying waste to her land.

Readers have engaged with the problematic language in 2:3 of "stripping her naked" in various ways. The Targum, for example, renders this as removing the Shekinah from the people, and thus taking away their glory (Cathcart and Gordon 1989, p. 31). A more common reading is offered by Rashi, who notes the language of being stripped naked "as on the day she was born" is similar to that in Ezek 16:4-5, and suggests that this refers to when the people were saved from Egypt (cf. Abarbanel). Jerome likewise draws on points of contact with Ezek 16, including the reference to fine clothing and ornaments. The fine things which were given to the people after Egypt will be taken away, and Israel will again be without a husband, as she was in Egypt (Jerome 2017). ${ }^{16}$ In the twentieth century, a number of potential parallels from the ANE and the HB were used to make sense of this reference to stripping. Texts from Babylonia and Nuzi were used to argue that stripping was used as part of divorce proceedings (Kuhl 1934; see critique from Day 2000). Others pointed to Exod 21:10, which notes a man's legal responsibility to clothe a wife; on this basis, Wolff and others argue that the stripping of the woman is a declaration of freedom from that legal obligation (Wolff 1974, p. 34; Sweeney 2000, pp. 28-29). These very specific readings have in recent decades fallen out of fashion (see Kelle 2005).

In the Targum, the reference to being laid bare in the wilderness in the second half of v. 3 is understood as referring to the wilderness wanderings of the generations that left Egypt — thus, according to the Aramaic, "My anger will fall on her as it fell on the people of the generation that transgressed my law in the wilderness" (Cathcart and Gordon 1989, p. 31). Variations on this wilderness theme have been picked up by ancient as well as more contemporary readers (Jerome, Rashi, Andersen and Freedman). Others, such as Cyril of Alexandria, see this as a spiritual wilderness, connecting Hosea to texts such as Amos 8:11-12 and Jer 6:7-8 (Cyril of Alexandria 2007, p. 68). Luther offers a Christological reading: drawing on John 7:37, the wilderness is an invitation to drink from the living waters (Luther [1556] 1975, p. 8; cf. Pusey 1885). According to Mays, the invocation of the wilderness and the parched land again points to the Canaanite fertility cult, in which "the land was considered the female to be fertilized by the rain of Baal" (Mays 1969, p. 38; cf. Wolff 1974, p. 34; for an argument against this, see Keefe 2001).

Moving to 2:6, the husband vows to "hedge her way with thorns, and build a wall against her." The thorns have led to various figurative readings; Gregory the Great understands these as those adversities which push us back toward God (Morals on the Book of Job 6.34.3; see Ferreiro 2003, p. 9; cf. Jerome 2017, p. 162). Cyril interprets this historically to 
refer to the wars, captivity, and servitude that would push the people back to God (Cyril of Alexandria 2007, pp. 70-71). More contemporary readers have noted that this language paints a picture of a wandering animal that must be contained (Mays 1969, p. 40; Andersen and Freedman 1980, p. 236).

In vv. 10-12, the speaker vows to uncover the woman's shame, as well as doing away with her feasts and festivals, and laying waste to her land. This devastation has, since antiquity, been understood as reference to the conquests of the Assyrians and the Babylonians (Jerome 2017; Nicholas of Lyra 1603; Radak [Rosenberg 1986]; Ewald [1840] 1875). In the modern era, as more focus was placed on cultic factors, the threat to the harvest and produce was seen as a critique of the northern adoption of the Baal cult (Wolff 1974, p. 38). However, the threat to uncover the woman's shame "in the sight of her lovers" can also be understood in political terms, as Assyria will see the weakness of Israel during this time of deprivation (Andersen and Freedman 1980, pp. 250-51).

In these verses we are told that Israel will be punished, and their things taken from them-the deprivation of these goods will make clear that these came from YHWH, and not from elsewhere (Mays 1969, p. 43). For most of history, the dominant voices within the interpretive traditions have not questioned the morality of this episode, nor God's or the husband's right to act in such a manner. Calvin, remarking on 2:13, suggests that the punishment of God was not only just but was necessary (Calvin [1559] 1846, p. 84).

However, recent decades have seen these assumptions scrutinized. As Marie-Theres Wacker notes, these are problematic images not least because "they facilitate the development of an image of God who is ready to use violence that then is misused to legitimate male and especially marital violence against women" (Wacker 2012, p. 374). Indeed, a number of feminist readers have highlighted that these verses indicate an escalating series of threats and punishments for the woman that are well known from abusive relationships: seclusion and isolation (2:6), withholding food and clothing (2:9), stripping and sexual humiliation (2:10), putting an end to celebration and happiness (2:11), and destroying land and produce (2:12). As Yee notes, the husband's actions in these verses suggests a strategy which "reflects the social methods of the patrilineal, honor/shame culture ... to control women" (Yee 1992, p. 199). When read in light of what we know about abusive relationships and cycles of violence, these are troubling images, whatever their intent.

\subsection{The Wooing: 2:14-23}

The tone of the chapter seems to change abruptly beginning in 2:14, as the husband speaks about the restoration of the fractured relationship (Andersen and Freedman 1980, p. 264). Verses 14-15 use evocative imagery, with the husband promising to "bring her into the wilderness and speak to her kindly". The wife will then respond "as in the days of her youth," as when she came out of Egypt. The LXX, however, offers a substantially different reading. Instead of bringing the woman into the wilderness, the Greek states that "I will deceive her;" and rather than responding positively as in the days of her youth, it says that "she will be brought low as in the days of her infancy" (Howard 2009).

The reference to the wilderness in v. 14 has led to various readings. Radak and other Jewish commentators note that the wilderness here might refer to exile (Rosenberg 1986, p. 14; cf. Theodoret of Cyr). Nevertheless, because Egypt is also mentioned, the most common assumption is that this refers to the exodus traditions (see the discussion of the haftarah reading, below). The woman's response, as in the days of her youth, is most often likened to the song of Moses after the crossing of the Red Sea (Rashi [Rosenberg 1986, p. 15]; cf. Nicholas of Lyra 1603; Calvin [1559] 1846; Gill 1763; Pusey 1885).

Christian readers have gone to great lengths to explain how the "alluring" (or "deception") of the woman is in fact a good thing. Cyril of Alexandria notes that the "seducing" of the woman is actually turning her away from things that are shameful and harmful (Cyril of Alexandria 2007, pp. 81-84). Theodore of Mopsuestia likewise sees the "seducing to the wilderness" as something difficult which leads to a positive outcome, as happens often in Scripture (Theodore of Mopsuestia 2004, p. 49). Pusey offers a similar reading: 
"God uses, as it were, Satan's weapons against himself. As Satan had enticed the soul to sin, so would God, by holy enticements and persuasiveness, allure her to Himself. God too hath sweetnesses for the penitent soul" (Pusey 1885, p. 35). Jerome, meanwhile, makes a Christological connection. After all the hardship that will come upon Israel, he writes, "then-that is, at the advent of Christ his son-he will open the hope of salvation and will provide an opportunity for repentance and will flatter her; for this is the meaning of I will allure her" (Jerome 2017, p. 165). Luther, too, sees the "allure" of Hosea as reference to the Gospel: "Through my apostles I will teach you a sweet doctrine that is different from the Law" (Luther [1556] 1975, p. 11).

The imagery of this chapter has been generative for interpreters down through the centuries. Luther speaks for many within the traditions when he says that "There is on earth no love more ardent than that between a groom and his betrothed" (Luther [1556] 1975 , p. 13). Nevertheless, the rhetoric of these verses has led to some concern, particularly in the contemporary era. As $\mathrm{O}^{\prime}$ Brien and others have observed, the actions in this chapter correlate quite closely with patterns of abusers, particularly within abusive marriages and relationships: emotional and verbal abuse, isolation, threats, and blaming are followed by a honeymoon period where all is forgiven ( $\mathrm{O}^{\prime}$ Brien 2008, pp. 33-34). For some, the reconciliation at the end of the chapter is too hasty after all that has gone before (Weems 1989). Further, the woman's voice is, again, silent in this chapter, as the husband speaks for her (Wacker 2012, p. 373). For these and other reasons, feminist readers have encouraged us to pause and reflect on the rhetoric of this chapter, and the underlying implications of the figurative elements which are employed.

\section{Hosea 1-3 in Liturgical Perspective}

The intriguing depiction of Hosea's marriage has meant that these opening chapters have had far-reaching influence, particularly in liturgy. In Christian traditions that use the Revised Common Lectionary, Hosea 1:2 is the beginning of a lectionary reading that extends through verse 10. This reading, on the seventh Sunday after Pentecost in Year C of the RCL cycle, is paired with Ps 85, Gen 18:20-32, Ps 138, Col 2:6-15(19), and Luke 11:1-13. The readings from Psalms and Genesis deal with issues of God's judgment and mercy, while the Gospel reading includes the Lord's Prayer, and the reminder that God is responsive to his people. ${ }^{17}$

Meanwhile, within Judaism, the second chapter of Hosea (Eng 1:10-2:20; Heb 2:1-22) is the Haftarah reading for the Torah reading Be-midbar, Numbers 1:1-4:20, in both the Ashkenazic and Sephardic traditions (Fishbane 2002, pp. 153-58). There are a number of thematic connections between these texts, including the reference to the time in the wilderness after coming out of Egypt in vv. 14-15. As Fishbane notes,

Following the covenant and the apostasy of the Golden Calf, this wandering with the Ark could thus be perceived as a time of purification prior to the nation's entrance into the Land.... The desert (midbar) serves a similar function in the haftarah. Speaking of a subsequent time, the prophet Hosea first shows how the seductions of idolatry have (again) perverted Israel's worship and deformed its religious consciousness. He then portrays how reconciliation will come about through God's tender speech to the people in the "wilderness".... The desert thus serves as a physical realm marking the transformation of the nation from bondage to freedom and a symbolic realm marking this same passage as a spiritual journey of rebirth. In both cases, the desert has a paradigmatic status in the life of the nation, marking change, transition, and new beginnings. (Fishbane 2002, p. 158)

Thus, both Christianity and Judaism have employed the first chapters of Hosea in liturgical traditions, drawing on the themes of returning to God and God's responsiveness to his people. Nevertheless, as Naomi Graetz has pointed out, the use of these chapters in liturgy and broader religious contexts is not unproblematic, for a number of the reasons outlined above: these chapters are relentlessly negative in their depiction of the woman; she is 
associated with infidelity and sexual promiscuity, while the male is left untouched; and she bears the brunt of both threats and punishment, which are seen as a means of wooing her back to her beloved. Indeed, she suggests that marriage and relationship imagery which cannot be accepted by both women and men is not a helpful metaphor in contemporary liturgical contexts (Graetz 1995, pp. 144-45).

\section{Conclusions}

This essay has examined a number of contested and contentious issues in the reception of Hos 1-3, exploring how readers throughout history have engaged with some of the more interesting and problematic aspects of the opening chapters of the book. The study focused on several key issues, including (1) debates concerning the literal or figurative nature of the marriage of Hosea and Gomer in chp. 1; (2) questions concerning how the woman of chp. 3 might be understood in relation to the events of chp. 1 ; (3) proposals on how to understand the marriage metaphor and its relation to Hosea's marriage; (4) ethical, theological, and rhetorical concerns raised by these chapters, including feminist critiques; (5) the role of Gomer's children in the opening chapter of the book; (6) the themes and rhetoric of chp. 2, including the punishment and wooing of the wife; and (7) the role of Hos 1-3 in the liturgical traditions of Judaism and Christianity.

As noted at the outset, the goal of this study was to offer soundings from diverse historical periods, religious traditions, and interpretive communities, which together give a sense of the wide-ranging ways in which readers have engaged with and made sense of Hosea. In particular, this essay sought to demonstrate that while specific questions related to Hosea have persisted through the years, the underlying assumptions and approaches to these questions have shifted considerably in various historical periods, which in turn has had a considerable impact on the way in which readers have engaged with this text.

Nowhere is this clearer than with the question of how to understand the marriage of Hosea and Gomer (or the infidelity therein). As noted above, this issue is raised consistently in the earliest commentaries and down through the present. Within this, both literal and figurative approaches are common at various points in history, shaped by diverse social, religious, and ethical assumptions and perspectives. Of particular note, however, are two influential developments of the past century: the rise of Canaanite fertility cult tropes in the twentieth century, inspired by form-critical approaches; and the shift evident from the late twentieth century where an increasing number of readers are less concerned with the question of whether or not elements of the text should be read literally or figuratively, and instead are much more concerned with the rhetoric of the text, and the ideas and perspectives which it espouses. These two developments reflect significant changes that were taking place in these periods: a greater focus on historicization in the former, and a turn toward rhetorical and ideological concerns in the latter-even if the underlying question of how to understand the marriage is still being addressed. One might also point to the question of ethical issues that have confronted readers of this prophetic text. In both Judaism and Christianity, a number of ethical and theological concerns are evident from antiquity, where we find readings concerned primarily with what these opening chapters say about God and the prophet, and the reputations of both figures. However, these ethical and theological questions have taken different shape over the past half century, particularly with the rise of feminist and other committed readings which have questioned and pushed back on the text's portrayal of the woman and her children, challenging the status quo of interpretive history. 18

Thus, while several broad questions and concerns are recognisable in diverse historical eras, the interpretive perspectives and approaches used to explore these questions have had a significant impact on the way in which readers have engaged with the opening chapters of Hosea throughout history. Taken together, what has long been understood as a text focusing on divine love and an invitation to repentance and return in the traditions of Judaism and Christianity is an increasingly difficult and problematic text for contemporary readers. Questions concerning the literal or figurative nature of Hosea's marriage-or 
historical reconstructions of Israel's infidelity—have given way to questions concerning the rhetoric of the text, and the diverse ethical and theological issues that are raised when one steps out of the dominant frames of reference that have shaped interpretation for most of the past two thousand years.

Of course, the early twenty-first century is not the end of the story, and there are many more voices to be heard in the reception of Hosea-past, present, and future. Nevertheless, the soundings offered here point to the multiplicity of ways in which the biblical text can and has been understood, and are a clear reminder that readers are shaped in diverse ways by their historical contexts, religious traditions, and indeed broader interpretive communities.

Funding: This research received no external funding.

Acknowledgments: I would like to thank Jonathan Kearney for his feedback on this research.

Conflicts of Interest: The author declares no conflict of interest.

\section{Notes}

Citing Matt 13:36.

On potential historical settings for the prophet and the book located broadly in the eighth century (Judean interpolations notwithstanding), see (Wolff 1974, pp. xxi-xxxii, 3-6; Andersen and Freedman 1980, pp. 31-52; and Sweeney 2000, pp. 3-7). For a reading which places the development of the book at a much later date in the post-exilic period, see (Ben Zvi 2005; Bos 2013).

3 References to the Hebrew of Hosea are drawn from (Gelston 2010) (BHQ). References to the Aramaic come from (Sperber 1902), with Targum translations from (Cathcart and Gordon 1989). Greek citations are from (Ziegler 1967), with English translations of the LXX from New English Translation of the Septuagint (Howard 2009).

4 Unless otherwise noted, all translations are from the NSRV. The Hebrew term used to describe Hosea's future wife, זנונים, has been translated in various ways. The LXX renders this with the root $\pi \mathrm{o} \varrho v \varepsilon i \alpha$, implying sexual immorality, the Peshitta offers "prostitution," while the Vulgate uses the term fornicatio. More recent translations, meanwhile, include terms such as harlotry (RSV; NASB), whoredom (KJV; NRSV), promiscuity (NIV), unfaithful (GNT), and prostitution (NLT; AMP). As several interpreters have noted, contrary to popular opinion, the text does not refer to Gomer as a זנה, the technical term for a prostitute; rather, her promiscuity signals sexual activity beyond the marriage relationship (Wacker 2012, p. 372). Yee thus prefers "wife of promiscuity" (Yee 1996, p. 216). While the text is silent regarding biographical details of the woman's life, both Jewish and Christian readers have claimed that Gomer was a well-known harlot at the time (Radak; Isho'dad of Merv).

$5 \quad$ Rashi at 1:2. Cf. b. Pesachim 87a.

6 Translation from William Davidson Talmud (Talmud: William Davidson Edition 2017), available at https:/ /www.sefaria.org (accessed on 4 May 2021)

Prima Secundae Partis (I.II) Q 94, A 5.

See, (e.g., Ewald [1840] 1875, pp. 244-45; Wellhausen 1892, pp. 102-4; Pusey 1885, p. 42; Harper 1905, p. 215; Rowley 1956, p. 224; Mays 1969, p. 55; Wolff 1974, p. 59; Yee 1996, p. 230).

9 For a helpful overview, see (Kelle 2009, pp. 186-93).

10 For a reassessment of this trope in antiquity more broadly, see (Budin 2008).

11 On the correlation of Hosea 1-3 and patterns of abuse in abusive relationships, see (Graetz 1995, pp. 126-45; O'Brien 2008, pp. 33-34).

12 See further discussion of modern interpretations in (Davies 1992, pp. 48-51, 107).

13 See, e.g., Targum; Rashi; Radak; Abarbanel; Jerome; Theodore of Mopsuestia.

14 Verse 7 introduces Judah to the equation ("but I will have pity on the house of Judah"), and there has been some disagreement on how to understand this reference. Andersen and Freedman see it as a continuation of v. 6: just as God will not show mercy on Israel, neither will he save Judah. They read the first clause of v. 7 as negative "even though the negative particle is not explicit" (Andersen and Freedman 1980, p. 194). In contrast to this, most readers interpret v. 7 as stating that Judah will be spared, in juxtaposition to Israel. Because the text states that this salvation will not come by war but, seemingly, by divine intervention, a common interpretation has been that this refers to Sennacherib's attack on Jerusalem as described in 2 Kgs 18-19 and Isa 31 (Ibn Ezra; Radak; Jerome; Theodore of Mopsuestia; Cyril; Luther). While not unanimous, many modern readers have suggested that this reference to Judah is likely a later Judean interpolation (Wellhausen 1892; Mays 1969; Emmerson 1984).

15 The English translations follow a different versification than the Hebrew traditions. In the Hebrew, chp. 1 has 9 verses, and chp. 2 has 25 verses. In English translations, chp. 1 has 11 verses, and chp. 2 has 23 verses. Thus, Hos. 1:10 in the English is 2:1 in the Hebrew, 2:1 in the English is 2:3 in the Hebrew, and so on, through the end of chp. 2. In what follows I offer only the English versification. 
See also (Theodore of Mopsuestia 2004; Cyril of Alexandria 2007; Calvin [1559] 1846; Gill 1763, Pusey 1885; Mays 1969; Andersen and Freedman 1980; Yee 2001).

17 Hosea's marriage has also been the subject of considerable attention in various contemporary retellings found in Christian literature and film, such as Francine Rivers' 2005 novel, Redeeming Love (see further examples in Krier 2016). Here God's divine love and unstoppable quest for his people's affection is mirrored in stories of human betrayal, retold in modern love stories where love and forgiveness prevail.

18 This in line with similar developments in biblical studies and indeed the humanities more broadly; see (Scholz 2017; Levine 2012).

\section{References}

Andersen, Francis I., and David N. Freedman. 1980. Hosea. AB 24. New York: Doubleday.

Aquinas, Thomas. 1920. The Summa Theologiz of St. Thomas Aquinas. Translated by The Fathers of the English Dominican Province. London: Burns Oates and Washbourne. First published 1485.

Balz-Cochois, Helgard. 1982. Gomer: Der Höhenkult Israels im Selbstverständnis der Volksfrömmigkeit: Untersuchungen zu Hosea 4, 1-5, 7. Frankfurt am Main: Peter Lang.

Batten, Loring Woart. 1929. Hosea's Message and Marriage. Journal of Biblical Literature 48: 257-73. [CrossRef]

Baumann, Gerlinde. 2003. Love and Violence: Marriage as a Metaphor for the Relationship between Yahweh and Israel in the Prophetic Books. Translated by Linda M. Maloney. Collegeville: Liturgical.

Ben Zvi, Ehud. 2005. Hosea. FOTL. Grand Rapids: Eerdmans.

Bird, Phyllis. 1989. 'To Play the Harlot': An Inquiry into an Old Testament Metaphor. In Gender and Difference in Ancient Israel. Edited by Peggy Day. Minneapolis: Fortress Press, pp. 75-94.

Bitter, Stephan. 1975. Die Ehe des Propheten Hosea. Eine auslegungsgeschichtliche Untersuchung. Göttingen: Vandenhoeck \& Ruprecht.

Bos, James M. 2013. Reconsidering the Date and Provenance of the Book of Hosea: A Case for Persian-Period Yehud. London: Bloomsbury T\&T Clark.

Brenner, Athalya, ed. 1995. A Feminist Companion to the Bible: The Latter Prophets. First Series; Sheffield: Sheffield Academic Press.

Budin, Stephanie L. 2008. The Myth of Sacred Prostitution in Antiquity. New York: Cambridge University Press.

Calvin, John. 1846. Commentaries on the Twelve Minor Prophets, Vol. 1: Hosea. Translated by John Owen. Edinburgh: Calvin Translation Society. First published 1559.

Cathcart, Kevin, and Robert Gordon. 1989. The Targum of the Minor Prophets. Wilmington: Michael Glazier.

Cyril of Alexandria. 2007. Commentary on the Twelve Prophets. Translated by Robert C. Hill. Fathers of the Church 115. Washington, DC: The Catholic University of America Press, vol. 1.

Davies, Graham I. 1992. Hosea. NCB 21. Grand Rapids: Eerdmans.

Day, Peggy L. 2000. Adulterous Jerusalem's Imagined Demise: Death of a Metaphor in Ezekiel XVI. Vetus Testamentum 50: 285-309. [CrossRef]

de Vaux, Roland. 1961. Ancient Israel: Its Life and Institutions. Translated by John McHugh. New York: McGraw-Hill.

Ego, Beate, Armin Lange, Hermann Lichtenberger, and Kristin De Troyer, eds. 2005. Minor Prophets. Biblia Qumranica 3B. Leiden: Brill.

Emmerson, Grace I. 1984. Hosea: An Israelite Prophet in Judean Perspective. JSOTSup 28. Sheffield: JSOT Press.

Ewald, Georg Heinrich August. 1875. Commentary on the Prophets of the Old Testament. Translated by J. Frederick Smith. Edinburgh: Williams and Norgate, vol. 1. First published 1840.

Ferreiro, Alberto, ed. 2003. The Twelve Prophets. Ancient Christian Commentary on Scripture 14. Downers Grove: IVP Academic.

Fischer, Eugene A. 1976. Cultic Prostitution in the Ancient Near East: A Reassessment. Biblical Theology Bulletin 6: 225-36. [CrossRef]

Fishbane, Michael. 2002. The JPS Bible Commentary: Haftarot. Philadelphia: Jewish. Publication Society.

Gelston, Anthony. 2010. The Twelve Minor Prophets. Biblia Hebraica Quinta 13. Stuttgart: Deutsche Bibelgesellschaft.

Gill, John. 1763. Exposition of the Old and New Testaments. Available online: https://www.sacred-texts.com/bib/cmt/gill/index.htm (accessed on 4 May 2021).

Gordis, Robert. 1954. Hosea's Marriage and Message. Hebrew Union College Annual 25: 9-40.

Gordon, Cyrus H. 1936. Hosea 2, 4-5 in the Light of New Semitic Inscriptions. Zeitschrift für die alttestamentliche Wissenschaft 54: 277-80.

Graetz, Naomi. 1995. God is to Israel as Husband Is to Wife: The Metaphoric Battering of Hosea's Wife. In A Feminist Companion to the Latter Prophets. First Series; Edited by Athalya Brenner. Sheffield: Sheffield Academic, pp. 126-45.

Gruber, Mayer I. 2017. Hosea: A Textual Commentary. LHBOTS 653. London: Bloomsbury T\&T Clark.

Harper, William Rainey. 1905. A Critical and Exegetical Commentary on Amos and Hosea. ICC. Edinburgh: T\&T Clark.

Howard, George E. 2009. The Twelve Prophets. New English Translation of the Septuagint. Available online: http:/ / ccat.sas.upenn.edu/ nets/edition/ (accessed on 4 May 2021).

Jeremias, Jörg. 1983. Der Prophet Hosea. ATD 24.1. Göttingen: Vandenhoeck \& Ruprecht.

Jerome. 2017. Three Books of Commentary on the Prophet Hosea to Pammachius. In Commentaries on the Twelve Prophets, Jerome. Edited by Thomas p. Scheck. Translated by Maria Veritas Marks, and Thomas p. Scheck. Ancient Christian Texts. Downers Grove: IVP Academic, vol. 2, pp. 148-261.

Julian of Eclanum. 2021. Commentaries on Job, Hosea, Joel, and Amos. Translated and Edited by Thomas p. Scheck. Ancient Christian Texts. Downers Grove: IVP Academic. 
Keefe, Alice A. 1995. The Female Body, the Body Politic and the Land: A Sociopolitical Reading of Hosea 1-2. In A Feminist Companion to the Bible: The Latter Prophets (First Series). Edited by Athalya Brenner. Sheffield: Sheffield Academic Press, pp. 70-100.

Keefe, Alice A. 2001. Woman's Body and the Social Body in Hosea. JSOTSup 338. London: Sheffield.

Kelle, Brad E. 2005. Hosea 2: Metaphor and Rhetoric in Historical Perspective. Atlanta: SBL.

Kelle, Brad E. 2009. Hosea 1-3 in Twentieth Century Scholarship. Currents in Biblical Research 7: 179-216. [CrossRef]

Krier, Theresa. 2016. Literature (Hosea). Encyclopedia of the Bible and Its Reception 12: 442-43.

Kuhl, Curt. 1934. Neue Dokumente zum Verständnis von Hos. 2, 4-15. Zeitschrift für die alttestamentliche Wissenschaft 52: 102-9. [CrossRef]

Landy, Francis. 1995. Hosea. Readings. Sheffield: Sheffield Academic Press.

Leith, Mary Joan Winn. 1989. Verse and Reverse: The Transformation of the Woman Israel in Hosea 1-3. In Gender and Difference in Ancient Israel. Edited by Peggy Day. Minneapolis: Fortress Press, pp. 95-108.

Levine, Peter. 2012. An Ethical Turn for the Humanities. In Rethinking the Humanities: Paths and Challenges. Edited by Ricardo Gil Soeiro and Sofia Tavares. Cambridge: Cambridge Scholars, pp. 129-42.

Long, Phillip J. 2013. Jesus the Bridegroom: The Origin of the Eschatological Feast as a Wedding Banquet in the Synoptic Gospels. Eugene: Wipf \& Stock.

Luther, Martin. 1975. Lectures on the Minor Prophets I: Hosea, Joel, Amos, Obadiah, Micah, Nahum, Zephaniah, Haggai, Malachi. Edited by Hilton C. Oswald. Translated by Richard J. Dinda. Luther's Works 18. St. Louis: Concordia. First published 1556.

Macintosh, Andrew. 1997. A Critical and Exegetical Commentary on Hosea. ICC. Edinburgh: T\&T Clark.

May, Herbert Gordon. 1932. The Fertility Cult in Hosea. The American Journal of Semitic Languages and Literatures 48: 73-98. [CrossRef] Mays, James L. 1969. Hosea. OTL. Philadelphia: Fortress.

Moughtin-Mumby, Sharon. 2008. Sexual and Marital Metaphors in Hosea, Jeremiah, Isaiah, and Ezekiel. Oxford: Oxford University Press.

Nicholas of Lyra. 1603. Bibliorum Sacrorum Cum Glossa Ordinaria. Edited by Fugensis Strabus. Venice: Apud Iuntas, vol. 4.

O'Brien, Julia M. 2008. Challenging Prophetic Metaphor: Theology and Ideology in the Prophets. Louisville: Westminster John Knox.

Pusey, Edward Bouverie. 1885. Minor Prophets: With a Commentary Explanatory and Practical and Introductions to the Several Books. New York: Funk \& Wagnalls, vol. 1.

Rosenberg, A. J. 1986. Mikraoth Gedeloth, The Book of the Twelve Prophets. New York: Judaica, vol. 1.

Rowley, Harold Henry. 1956. The Marriage of Hosea. Bulletin of the John Rylands Library 39: 200-33. [CrossRef]

Rudolph, Wilhelm. 1966. Hosea. KAT 13.1. Gütersloh: Gerd Mohn.

Scholz, Susanne. 2017. Introducing the Women's Hebrew Bible: Feminism, Gender Justice, and the Study of the Old Testament, 2nd ed. London: T \& T Clark.

Setel, T. Drorah. 1985. Prophets and Pornography: Female Sexual Imagery in Hosea. In Feminist Interpretation of the Bible. Edited by Letty M. Russell. Philadelphia: Westminster.

Sherwood, Yvonne. 1996. The Prostitute and the Prophet: Hosea's Marriage in Literary-Theoretical Perspective. JSOTSup 212. Sheffield: JSOT Press.

Sperber, Alexander. 1902. The Bible in Aramaic, vol. III: The Latter Prophets according to Targum Jonathan. Leiden: Brill.

Sweeney, Marvin A. 2000. The Twelve Prophets. Berit Olam. Collegeville: Michael Glazer, vol. 1.

Talmud: William Davidson Edition. 2017. Available online: https:/ /www.sefaria.org/texts/Talmud (accessed on 4 May 2021).

Theodore of Mopsuestia. 2004. Commentary on the Twelve Prophets. Translated by Robert C. Hill. Fathers of the Church 108. Washington, DC: The Catholic University of America Press.

Volz, Paul. 1898. Die Ehegeschichte Hoseas. Zeitschrift für Wissenschaftliche Theologie 6: 321-35.

von Rad, Gerhard. 1968. The Message of the Prophets. Translated by D. M. G. Stalker. London: SCM. First published 1967.

Wacker, Marie-Theres. 1996. Figurationen des Weiblichen im Hosea-Buch. Freiburg: Herder.

Wacker, Marie-Theres. 2012. Hosea. In Feminist Biblical Interpretation: A Compendium of Critical Commentary on the Books of the Bible and Related Literature. Edited by Luise Schottroff and Marie-Theres Wacker. Translated by Lisa E. Dahill, Everett R. Kalin, Nancy Lukens, Linda M. Maloney, Barbara Rumscheidt, Martin Rumscheidt, and Tina Steiner. Grand Rapids: Eerdmans, pp. 371-85.

Weems, Renita J. 1989. Gomer: Victim of Violence or Victim of Metaphor? Semeia 47: 87-104.

Wellhausen, J. 1892. Die Kleinen Propheten. Skizzen und Vorarbeiten. Berlin: Reimer, vol. 5.

Wolff, Hans Walter. 1974. Hosea. Hermeneia. Philadelphia: Fortress.

Yee, Gale A. 1992. Hosea. In The Women's Bible Commentary. Edited by Carol A. Newsom and Sharon H. Ringe. Louisville: Westminster/John Knox, pp. 195-202.

Yee, Gale A. 1996. The Book of Hosea. In The New Interpreter's Bible. Nashville: Abingdon, vol. 7, pp. $197-297$.

Yee, Gale A. 2001. 'She Is Not My Wife and I Am Not Her Husband': A Materialist Analysis of Hosea 1-2. BibInt 9: 345-83. [CrossRef]

Ziegler, J. 1967. Minor Prophets [Duodecim Prophetae]. In Septuaginta. Vetus Testamentum Graecum Auctoritate Academiae Scientiarum Gottingensis Editum, 2nd ed. Göttingen: Vandenhoeck \& Ruprecht. 